\title{
Immunocytochemical study of gastrintestinal endocrine cells in insectivorous bats (Mammalia: Chiroptera)
}

\author{
Santos, $C M{ }^{\text {a* }}$, Nascimento, $A A .^{\mathrm{b}}$, Peracchi, $A L .^{\mathrm{c}}$, \\ Sales, A. ${ }^{\mathrm{b}}$, Mikalauskas, JS. ${ }^{\mathrm{a}}$ and Gouveia, $S F^{\mathrm{d}}{ }^{\mathrm{d}}$ \\ aPós-graduação em Biologia Animal, Universidade Federal Rural do Rio de Janeiro - UFRRJ, \\ Rod. BR 465, Km 07, CEP 23890-000, Seropedica, RJ, Brazil \\ 'Laboratório de Histologia e Embriologia, Universidade Federal Rural do Rio de Janeiro - UFRRJ, \\ Rod. BR 465, Km 07, CEP 23890-000, Seropedica, RJ, Brazil \\ 'Laboratório de Mastozoologia, Universidade Federal Rural do Rio de Janeiro - UFRRJ, \\ Rod. BR 465, Km 07, CEP 23890-000, Seropedica, RJ, Brazil \\ dDepartamento de Biologia Animal, Universidade Federal de Sergipe - UFS, \\ Av. Marechal Rondon, s/n, Jardim Rosa Elze, CEP 49100-000, São Cristóvão, SE, Brazil \\ *e-mail: claricemachado@yahoo.com.br \\ Received January 30, 2007 - Accepted July 5, 2007 - Distributed August 31, 2008
}

(With 17 figures)

\begin{abstract}
The regional distribution and relative frequency of endocrine cells in the stomach and intestine of Phyllostomidae: Lonchorhina aurita and Molossidae: Molossus molossus bats were studied immunohistochemically. Three types of immunoreactive (IR) endocrine cells - to serotonin (5-HT), gastrin (GAS) and enteroglucagon (GLUC) - were found in the gastric mucosa and four types of IR cells were identified in the intestinal mucosa. This study showed an interespecfic difference in the regional distribution and relative frequency of endocrine cells in the Chiropteran alimentary tract.
\end{abstract}

Keywords: endocrine cells, stomach, intestine, insectivorous bats.

\section{Estudo imunocitoquímico das células endócrinas gastrintestinais de morcegos insetívoros (Mammalia: Chiroptera)}

\begin{abstract}
Resumo
A distribuição regional e a frequiência relativa das células endócrinas no estômago e intestino dos morcegos insetívoros Phyllostomidae: Lonchorhina aurita e Mormoopidae: Molossus molossus foram estudadas pelo método de imunohistoquímica. Três tipos de células endócrinas imunorreativas (IR) à serotonina (5-HT), gastrina (GAS) e enteroglucagon (GLUC) foram localizadas na mucosa gástrica e quatro tipos de células endócrinas IR à 5-HT, GAS, colecistoquinina (CCK) e GLUC foram identificadas na mucosa intestinal. Este estudo mostrou uma diferença interespecífica na distribuição regional e na frequiência relativa das células endócrinas no trato alimentar de Chiropteros.
\end{abstract}

Palavras-chave: células endócrinas, estômago, intestino, morcegos insetívoros.

\section{Introduction}

Gastrintestinal endocrine cells were dispersed throughout the epithelia and gastric glands of the alimentary tract. These cells produce many biologically active polypeptides and amines, some of them hormones (Bayliss and Starling, 1902). These hormones have important functions in the overall regulation of the digestive process, such as nutrient absorption, the secretion of intestinal and associated glands, gut motility and intetinal blood flow (Deveney and Wal, 1983).

The role of endocrine cells and their respective regulator peptides has attracted the interest of many investigators, who have described them in the gastrintestinal tract (GIT) of other vertebrates, such as reptiles ( $\mathrm{Ku}$ et al. 2001), fish (Pan et al., 2002), birds (Rawdon and Andrew, 
1981; Nascimento et al., 2007) and mammals (Ku et al., 2004a and $\mathrm{Ku}$ et al., 2004b), seeking to establish the morphological role of these cells and respective peptides, responsible for regulating numerous body functions.

The investigation of gastrintestinal endocrine cells has proved useful in phylogenetic studies (D'Este et al., 1994). In addition, the regional distribution and relative frequency of these endocrine cells has been found to vary with the animal species and feeding habits (Solcia et al., 1975). Fifteen types of endocrine cells have been demonstrated in the gastrintestinal tract of bats by immunohistochemistry. Nine types of endocrine cells have been shown in the vampire bat Desmodus rotundus (Yamada et al.,1984), eleven in the insectivorous bats Pipistrellus abramusi and Plecotus auritus (Yamada et al., 1988), eight in nectarivorous and frugi-nectarivorous bats Anoura caudifer and Carollia perspicillata (Ashihara et al., 1999) four in the frugivorous bats Artibeus cinerius and Sturnira lilium (Santos et al., 2008) and ten in the piscivorous Noctilio leporinus (Komori et al., 2000). These studies reveal interspecific differences and suggest correlation between endocrine cell distribution and feeding habits.

This work aimed to analyze the regional distribution and relative frequency of immunoreactive (IR) endocrine cells to serotonin, gastrin, CCK and enteroglucagon in the gastric mucosa and intestine mucosa of Phyllostomidae Lonchorhina aurita (Thomes, 1901) and Molossidae Molossus molossus (Wagner, 1843), both insectivorous bats, using immunohistochemistry.

\section{Materials and Methods}

\subsection{Collection of samples and tissue procedures}

Six bats were used; three L. aurita and three M. molossus. We captured the L. aurita specimens at night in Casa de Pedra cave, SE $\left(10^{\circ} 50^{\prime} 100^{\prime \prime} \mathrm{S}\right.$ and $\left.37^{\circ} 27^{\prime} 08^{\prime \prime} \mathrm{W}\right)$, Brazil, and the specimens of M. molossus at Rio de Janeiro Federal Rural University (UFRRJ), RJ, Brazil. The bats were sacrificed by ether inhalation and the alimentary tracts were removed and fixed with Bouin fluid for 6 hours. After fixation, they were separated into the five regions as shown in Figure 1. The tissues were dehydrated in a graded series of ethanol solutions and embedded in parafin (Histosec - Merck). Sections of $5 \mu \mathrm{m}$ thickness were prepared on glass slides precoated with $0.1 \%$ poly-L-lysine (Sigma Chemical Co., Saint Quentin Fallavier, France).

\subsection{Primary antisera}

The primary antisera were used for both the specificity controls and the study of the interrelationship of cells immunoreactive to regulatory peptides and biogenic amine. They included rabbit serotonin (5-HT) antiserum (diluted 1:8,000; S 5545 - Sigma-Aldrich,inc.), rabbit gastrin antiserum (diluted 1:1,000; G 0785 - SigmaAldrich, inc.), rabbit colecystokinin (CCK) antiserum (diluted 1:8,000; C 2581 - Sigma-Aldrich, inc.), mouse glucagon (enteroglucagon) antiserum (diluted 1:2,000; G 2654 - Sigma-Aldrich, inc.). We referred to the endo-

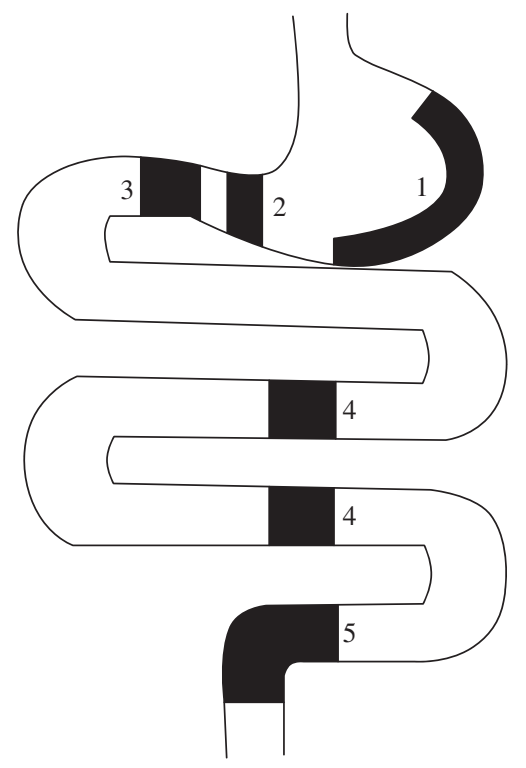

Figure 1. Schematic drawing of the digestive tract illustrating regions sampled from $L$. aurita and M. Molossus (Modified from Komori et al., 2000). 1) Stomach, fundic region, 2) Stomach, pyloric region, 3) Intestine I - duodenum, 4) Intestine II, jejunum/ileum, and 5) Intestine III - large intestine and rectum.

crine cells immunoreactive to glucagon antiserum with code G 2654 as enteroglucagon-IR cells, since the antiserum showed cross-reaction with pancreatic glucagon and enteroglucagon.

\subsection{Single antigen immunocytochemistry}

For the immunocytochemical procedure, the sections were processed at room temperature in a humid chamber by avidin-biotin-peroxidase complex (ABC). Microscope slides with fixed sections were treated for 2 hours at room temperature with a non immune serum (goat; Sigma), diluted 1:100 in Phosphate Buffered Saline (PBS), and then incubated overnight at $4{ }^{\circ} \mathrm{C}$ with four of two primary region-specific antisera. The standard antibody dilutions used during immunocytochemistry were $1: 8,000$ for serotonin (5-HT); 1:1,000 for gastrin; $1: 8,000$ for colecystokinin (CCK) and 1:2,000 for glucagon (enteroglucagon). The antibody dilutions were made with $1 \%$ PBS in TBS. The peroxidase was reacted with a mixture of 3.3'-diaminobenzidine tetrahydrochloride (DAB) - Sigma (0.1\% in PBS) and $0.02 \% \mathrm{H}_{2} \mathrm{O}_{2}$. The slides were rinsed several times with deionized water, dehydrated through a series of alcohols and methylcyclohexanes, and coverslip with Entelan (Merck).

\subsection{Primary antiserum specificity controls}

In the present study, the immunocytochemical localization of regulatory peptides and biogenic amine (5-HT) in the endocrine cells was investigated by use of the monoclonal antiserum. Consequently, the region specificity of this antibody was tested in the 
immunocytochemical system and the specificity of this antiserum was examined by controls.

\subsection{Immunocytochemical tests}

The specificity of immunostaining was demonstrated not only by the usual specificity tests (method controls), but also by extensive cross-reaction studies (antibody controls), as recommended previously (Heyderman, 1979). Method controls to validate the specificity of the binding of immunocytochemical reagents with tissue included: 1) omission of the primary antiserum, 2) replacement of the primary antiserum with nonimmune serum, 3) dilution profile of the primary antiserum using doubling dilutions on serial sections, 4) influence of the salt content (up to $0.5 \mathrm{~m}$ ) of the buffer, and 5) complement-deprived antisera. In addition, controls for the specificity of double labeling were performed as follows: 1) using nonimmune serum as the first layer, and 2) using the labeled antisera without the presence of one or both primary antisera. Antibody controls to determine the specificity of interaction between the primary antiserum and the tissue-bound antigen were also used.

\subsection{Photomicrographs, cell counts and statistical analysis}

Photomicrographies on an Olympus DX-41 microscope, were performed to specifically identify the endocrine-immunoreactive cells. The relative frequency of immunoreactive cells in each region was based on the number of immunoreactive cells per unit area $\left(0.25 \mathrm{~mm}^{2}\right)$ of tissues and calculated using a computerized image analyzer (Image Pro-Plus software). The frequency of occurrence was as mean $+\mathrm{SD}$ (standard deviation) per unit area.

\section{Results}

\subsection{Types, distributional features of GI endocrine cells in GIT of two insectivorous bats}

Four types of immunoreactive cells to serotonin (5-HT), gastrin (GAS), colecystokinin (CCK) and enteroglucagon (GLUC) were identified in gastric and intestinal mucosa of M. molossus and L. aurita. Three types of IR-cells to 5-HT, GAS and GLUC were identified in gastric mucosa and all cell types were found in the intestinal mucosa. The regional distribution and relative frequency of the endocrine cells for both species of bats are listed in Table 1. No positive reactions were detected in the negative control sections.

\subsection{Serotonin-immunoreactive cells (5-HT)}

5-HT-IR cells detected throughout the whole GIT of two bats were the most predominant gastrintestinal endocrine cells. They were more frequent in the pyloric region of M. molossus (54.7 \pm 13.8 cells / $0.25 \mathrm{~mm}^{2}$ ) and of L. aurita (38.0 \pm 17.6$)$ (Figures 2 and 3) than in other regions. In the fundic region of the stomach of M. molossus and L. aurita, the 5-HT-IR cells were predominantly oval without cytoplasmatic processes. Their distribution in the stomach was primarily in the medial and basal portion of the fundic glands (Figure 4). In the pyloric region of $M$. molossus, these 5-HT-IR cells were oval and spindle-shaped with a cytoplasmatic process (Figure 2). In the pyloric region of L. aurita, the predominant form was oval, found in both species more frequently in the middle than the basal part of the gland (Figure 5). Their relative frequency varied along the intestine, but they were always continuous and abundant. The 5-HT-IR cells were observed in the superficial epithelium and in the intestinal glands. In M. molossus, small numbers of these IR-cells were found in the duodenal glands (Figure 6). These endocrine cells were piriform and frequently had a cytoplasmic process toward the glandular lumen, so are classified as open type (Figure 7).

\subsection{Gastrin-immunoreactive cells}

Gastrin-immunoreactive cells were abundant and strongly marked in the pyloric glands in both species of bats (Figure 8). These endocrine cells were frequently oval or spindle-shaped (Figure 9), with the most frequent being the closed type or without the presence of a cytoplasmic process. The distribution in both species was restricted to the pyloric gland. We did not observe any between of superficial epithelium cells (Figure 10). They were more numerous in L. aurita $(46.8 \pm 13.2)$ than in M. molossus (42.2 \pm 3.8$)$. In the intestine, there was only weak reaction in the gastroduodenal region.

\subsection{Colecystokinin-immunoreactive cells (CCK)}

The CCK-IR cells were detected in the pyloric glands of $M$. molossus. These endocrine cells were frequently oval in shape and open type. These IR-cells were observed in both species, throughout the intestine (Figures 11 and 12). Their frequency was roughly the same in both species and they were most abundant in intestine I $(30.9 \pm 4.0$ in $M$. molossus e $27.7 \pm 3.9$ in L. aurita). No CCK-IR cells were detected in the duodenal gland of $L$. aurita, but there were a few in M molossus. Their distribution was observed in both species in the intestinal glands and the superficial epithelium, being the open type (Figure 13).

\subsection{Glucagon (enteroglucagon)-immunoreactive cells}

These cells were observed in the fundic $(3.7 \pm 1 / 1.7 \pm .0)$ and pyloric $(1.4 \pm 0.6 / 2.2 \pm 0.3)$ regions of $L$. aurita and M. molossus. They were oval or irregular in shape, open to the lumen in the pyloric gland (Figure 14). In the intestine their occurrence was rare, but was detected in all portions of L. aurita (Figure 15). Some IR-cells were observed in the duodenal glands of M. molossus (Figure 16), as well as in the opening of the choledocum duct (Figure17).

\section{Discussion}

The regional distribution patterns and relative frequencies of gastrintestinal endocrine cells show remark- 
Table 1. Distribution and relative frequency of gut endocrine cells of L. aurita and M. molossus.

\begin{tabular}{lcccc}
\hline \multicolumn{1}{c}{ Region } & Serotonin & Gastrin & CCK & Enteroglucagon \\
\hline Stomach-fundus & $36.5 \pm 13,9 * / 32.7 \pm 3.7$ & $\mathrm{f} / 0$ & $0 / 0$ & $3.7 \pm 1 / 1.7 \pm 0$ \\
Stomach-pylorus & $38 \pm 17.6 / 54.7 \pm 13.8$ & $46.8 \pm 13.2 / 42.2 \pm 3.8$ & $0 / \mathrm{f}$ & $1.4 \pm 0.6 / 2.2 \pm 0.3$ \\
Intestine I & $24,2 \pm 3.1 / 40.3 \pm 9.3$ & $\mathrm{f} / \mathrm{f}$ & $30.9 \pm 4 / 27.7 \pm 3.9$ & $4.6 \pm 0.3 / 0$ \\
Intestine II & $14.8 \pm 8.1 / 7.7 \pm 2.9$ & $0 / 0$ & $12.1 \pm 2 / 15 \pm 2.6$ & $\mathrm{f} / 0$ \\
Intestine III & $27.8 \pm 9.3 / 8.7 \pm 3.2$ & $0 / 0$ & $12.1 \pm 4 / 5.6 \pm 0.7$ & $4.0 \pm 0.5 / 0$ \\
\hline
\end{tabular}
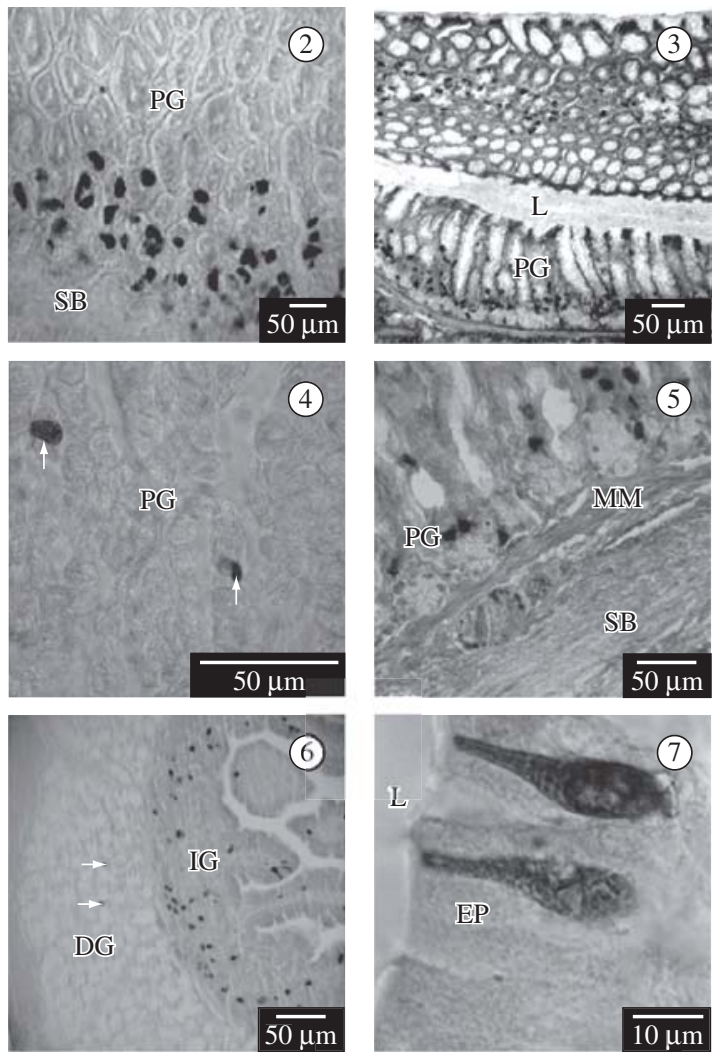

Figures 2-7. Photomicrographs serotonin-immunoreactive cells. 2) M. molossus pyloric region; 3) L. aurita pyloric region; 4) Oval form of the cell located in the pyloric gland of M. Molossus (arrow); 5) Intestine I of L. aurita with ovoid and triangular cells in the intestinal glands; 6) Intestine I of M. molossus with markings in the duodenal glands (arrow); and 7) Intestine II of M. molossus with piriform interepithelial cells, with cytoplasmatic process turned to the lumen1. PG: Pyloric glands; SB: Submucosa; L: Lumen; EP: Epithelium; MM: Muscularis Mucosa; DG: Duodenal Glands; IG: Intestinal Glands.

able differences in animal species and in different parts of the gastrintestinal tract (Alumets et al., 1977).

Cells immunoreactive to 5-HT, gastrin, CCK and enteroglucagon were identified in $M$. molossus and $L$. aurita, which were classified in different families, Mormoopidae and Phyllostomidae, respectively.
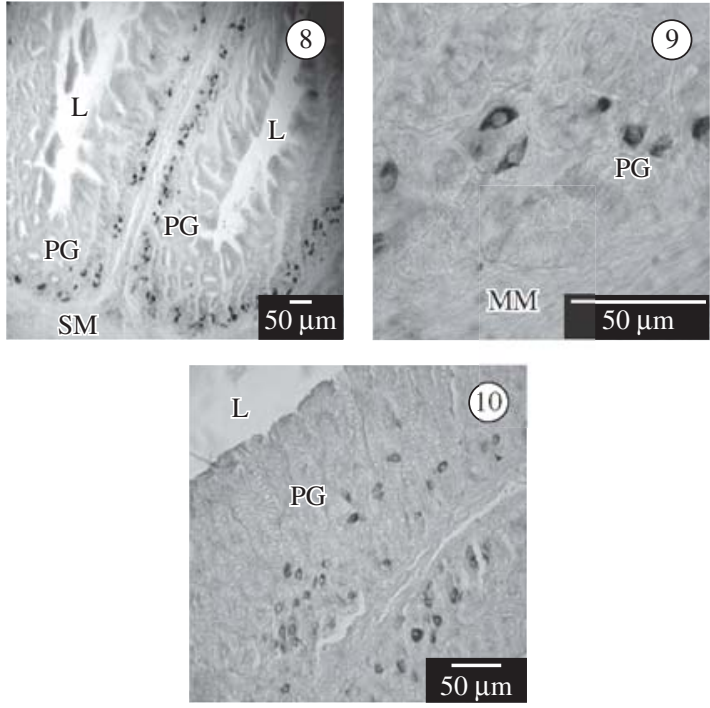

Figures 8-10. Photomicrographs of gastrin-immunoreactive cells in the pyloric region 8) M. molossus, note the location of positive cells in the region of the pyloric gland; 9) M. molossus with spindle-shaped cell; and 10) L. aurita, cells positioned along the pyloric gland, in the medial to basal part of the gland. PG: Pyloric Glands; SB: Submucosa; L: Lumen; MM: Muscularis Mucosa.

Serotonin is secreted by the enterocromafin cells (EC), widely distributed in the nervous system and in the gastro-entero-pancreatic endocrine cells (Richter et al., 1986; El-Salhy et al., 1985). EC Cells constitute the largest endocrine cell population in the gastrintestinal tract and produce more than $90 \%$ of all serotonin synthesized in the body (Ahlman and Nilsson, 2001). This cell type has been characterized by the large amount of 5-HT stored, which gives them the ability to reduce silver salts (silver affinity) and chromium salts (chromium affinity).

The serotonin have been identified in the gastrintestinal tract of Pipistrellus abramus and Plecotus auritus sacrimontis (Yamada et al., 1988). These authors identified 5-HT-IR cells along the entire GIT of P. abramus, and found an absence of these cells in the end intestine of $P$. auritus. In M. molossus, there was also no marking in these structures. In the intestine, the open type cells were abundant, indicating that these cells can probably secrete 

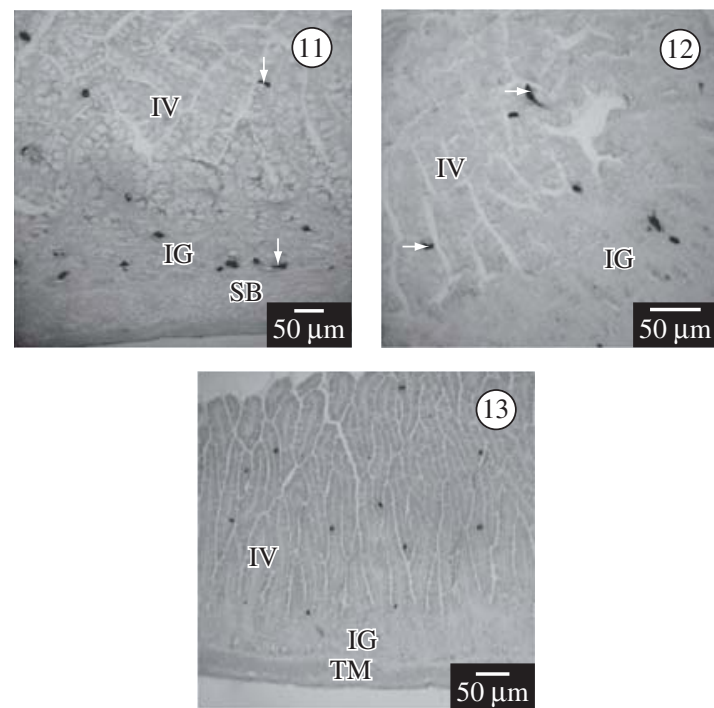

Figures 11-13. Photomicrographs of cholecystokinin (CCK)-immunoreactive cells. 11-12) Intestine II and III of L. aurita, respectively. Note the piriform shape with the presence of cytoplasmatic process (arrow); cells located in the interepithelial region and in the intestinal glands; and 13) Intestine I of M. molossus. Piriform interepithelial cells. SB: Submucosa; TM: Tunica Muscularis; IV: Intestinal Villi; IG: Intestinal Glands.
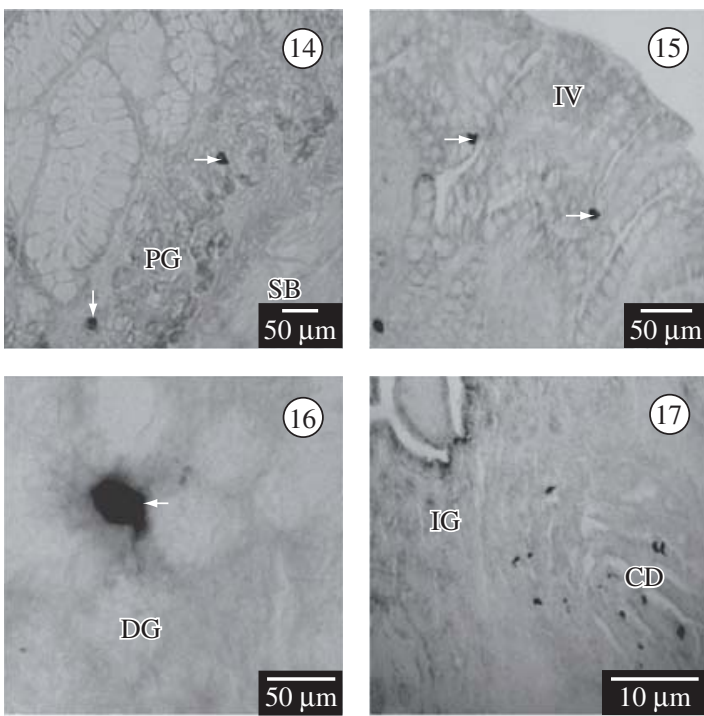

Figures 14-17. Photomicrographs of immunoreactive cells to enteroglucagon. 14) Pyloric region of M. molossus. Location of positive cells in the glandular region (arrow); 15) Intestine III of M. molossus, interepithelial location (arrow); 16) Duodenal gland of M. molossus, ovoid cell; and 17) Intestine I of M. molossus with the labeling in the opening of the choledocum duct. PG: Pyloric Glands; SB: Submucosa; IV: Intestinal Villi; DG: Duodenal Glands; IG: Intestinal Glands; CD: Choledocum Duct.
5-HT by the paracrine pathway (Ashihara et al., 1999). A few cells have been found in the duodenal glands of the frugi-nectarivorous bat $C$. perspicillata and in the pyloric region of nectarivorous A. caudifer (Komori et al., 2000).

Gastrin is a linear peptide hormone produced by $\mathrm{G}$ cells of the pyloric antrum of the stomach and duodenum. The ultrastructure of these cells shows the existence of microvilli in the apical surface, interdigitation with the neighboring cells and pleating of the cell membrane in the basal region (Solcia et al., 1975). This hormone acts by increasing the force of antrum contractions and the constriction of the pyloric sphincter; the overall effect of these actions being to reduce the speed of gastric emptying. Gastrin is regulated by epidermal growth factors in this way in both rats and human beings (Koh and Wang, 1995).

Gastrin-IR cells were detected in the gastric glands of the pyloric region of both species studied here, but have not been detected in the fundic region of $C$. perspicillata, A. caudifer (Ashihara et al., 1999) and Noctilio leporinus (Komori et al., 2000). In. A. caudifer they have also been found in small numbers in the fundic region (Ashihara et al., 1999). In this study, these cells were not observed anywhere in the intestinal tract except in the gastroduodenal junction. Nevertheless, these have been reported throughout all the intestine of C. perspicillata, A. caudifer and in the initial portions of the intestine of $N$. leporinus (Ashihara et al., 1999; Komori et al., 2000).

CCK plays a key role in facilitating digestion within the small intestine. It is secreted from mucosal epithelial cells in the intestine and stimulates delivery into the small intestine of digestive enzymes from the pancreas and bile from the gallbladder. Moreover, it is also produced by neurons in the enteric nervous system, and is widely and abundantly distributed in the brain (Moran and Schwartz, 1994). CCK acts by inhibiting food ingestion in mammals. It also contributes to excitatory transmission and also stimulates the secretion of pepsinogen by the chief cells.

The result of this work, when compared with others on chiropterans, showed a greater difference with respect to the distribution and relative frequency of cells immunoreactive to CCK. The main aspect is that we observed these cells throughout the intestine, mainly among the epithelial components. However, in the insectivorous P. abramus and $P$. auritus sacrimontis, this has only been reported in low frequency in the nearby region of the intestine (Yamada et al., 1988). In frugi-nectarivorous, nectarivorous (Ashihara et al., 2000) and piscivorous bats (Komori et al., 2000), the absence of these immunoreactive cells in all intestinal regions has been reported. This absence has been justified by the possible difference in the molecular form of this hormone or its real absence from these species. Since $L$. aurita is from the same family as $C$. perspicillata and A. caudifer (the Phillostomidae), the existence of marked molecular differences is an unexpected result. 
Glucagon is a single-chain peptid with 29 amino acid residues. One of its more known actions is to provoke hiperglicemy through hepatic glicogenolisis. It also has other biological actions, such as lipolysis and cetogenesis (Foa et al., 1957).

The distribution and relative frequency of enteroglucagon cells was different according to the species studied. In M. molossus their distribution was restricted to the intestine. In $L$. aurita this peptide was observed in some cells in the fundic and the pyloric region, a fact not yet reported in chiropterans, since in piscivorous, frugi-nectarivorous and nectarivorous bats its presence is restricted to the fundic portion of the stomach and the intestine. This difference suggests that diet alone may not interfere in the distribution and relative frequency of these cells, since in insectivorous $P$. abramus and $P$. auritus sacrimontis these have also not been observed in the final portion of the stomach (Yamada et al., 1988).

The regional distribution and relative frequency of the immunoreactive cells in M. molossus and L. aurita is similar to that of other species of chiropterans (Yamada et al., 1988; Ashihara et al., 1999; Komori et al., 2000; Santos et al., 2008). However, in this study some characteristics observed mainly in the cells immunoreactive to CCK and to enteroglucagon differed from the other species of chiropterans previously studied.

In conclusion, the regional distribution and relative frequency of the endocrine cells in the insectivore bats was similar to those observed for other bats with the same feeding habits, but interspecific differences were observed, mainly related to CCK-IR cells. These differences might be of help in understanding the evolution of the digestive tract in relationship to the partitioning by nutrient resources and evolutional niches. Immunohistochemical and ultrastructural studies of the gastrintestinal tract of bats, including those in the present study, have revealed apparent interspecies differences among them. However, we hope these findings can contribute to future studies to validate or reject the correlation between feeding habits and frequency of endocrine cells in bats.

Acknowledgements - We thank Ilza Lucas Coelho Meirelles, Patrício Adriano da Rocha and Victor Villas-Boas Silveira for their collaboration; and CAPES (Office for Improvement of University Education) for the Master's scholarship given to the first author in the Postgraduate Program in Animal Biology at Rio de Janeiro Federal Rural University.

\section{References}

AHLMAN, H. and NILSSON, O., 2001. The gut as the largest endocrine organ in the body. Ann. Oncol., vol. 12, no. (suppl. 2), p. S63-S68.

ALUMETS, J., SUNDLER, F. and HAKANSON, R., 1977. Distribuition, ontogeny and ultrastructure of somatostatin immunoreactive cells in the pancreas and gut. Cell Tissue Res., vol. 185 , no. 4 , p. 467-479.
ASHIHARA, N., TADDEI, VA., HONDO, E., KITAMURA, N., PAI, VD., CAMPOS, J., CHOLIQ, N. and YAMADA, J., 1999. An immunohistochemical study of gut endocrine cells in Nectarivorous and Frugi-nectarivorous Phillostomid Bat (Chiroptera:Anoura caudifer and Carollia perspicillata). Jpn. J. Zoo. Wildl. Med., vol 4, no. 2, p. 125-133.

BAYLISS, WM. and STARLING, EH., 1902. The mecanism of pancreatic secretion. J. Phisiol., vol. 28, no. 5, p. 325-353.

D'ESTE, L., BUFFA, R., PELAGI, M., SICCARDI, AG., RENDA, T., 1994. Immunohistochemical localization of chromogranin A and B in the endocrine cells of the alimentary tract of the green frog, Rana esculenta. Cell Tissue Res., vol. 277 , no. 2 , p. $341-349$

DEVENEY, CW. and WAY, LW., 1983. Regulatory peptides of gut. In Greenspan, FS. and Forsham, PH. (Eds.). Basic and Clinical Endocrinollogy. Asian edn. Singapore: Maruzen. p. 479-499.

EL-SALHY, M., WINDER, E. and LUNDQVIST, M., 1985. Comparative study of serotonin-like immunoreactive cells in the digestive tract of vertebrates. Biomed. Res., vol. 6, p. 371-375.

FOA, PP., GALANSINO, G. and POZZA, G., 1957. Glucagon, a second pancreatic hormone. Recent. Prog. Horm. Res., vol. 13, p. 473-503.

HANDLEY-JR, CO., 1967. Bats of the canopy of an Amazonian forest. Atas Simp. Biota Amazonica (Zool.), vol. 5, p. 211-215.

HEYDERMAN, E., 1979. Immunoperoxidase techniques in histopathology: aplications, methods and controls. J. Clin. Pathol., vol. 32, no. 10, p. 971-78.

KOMORI, M., TADDEI, A., HONDO, E., KITAMURA, N., PAI, VD., CHOLIQ, CN. and YAMADA, J., 2000. An immunohistochemical study of gut endocrine cells in Piscivorous Bat (Chiroptera: noctilio leporinus). Jpn. J. Zoo. Wildl. Med., vol. 5 , no. 1, p. 45-54.

$\mathrm{KOH}$, TJ. and WANG, TC., 1995. Molecular cloning and sequence of murine gastrin gene. Biochem. Biophys. Res. Commun., vol. 216, no. 1, p. 34-41.

KU, SK., LEE, HS., LEE, JH. and PARK, KD., 2001. An immunohistochemical study of the encocrine cells in the alimentary tract of Red-Eared Slider (Trachemys scripta elegans). Anat. Histol. Embriol., vol. 30, no. 1, p. 33-39.

KU, SK., LEE, HS. and LEE, JH., 2004a. Immunohistochemical study of gastrointestinal Endocrine Cells in the BALB/c mouse. Anat. Histol. Embryol., vol. 33, no. 1, p. 42-48.

-, 2004b. Immunohistochemical study of gastrointestinal Endocrine Cells in the ddY mice. J. Vet. Sci., vol. 5, no. 2, p. 87-95.

MORAN, TH. and SCHWARTZ, GI., 1994. Neurobiology of cholecystokinin. Crit. Rev. Neurobiol., vol. 9, p. 1-28.

NASCIMENTO, AA., SALES, A., CARDOSO, TRD., PINHEIRO, NL. and MENDES, RMM., 2007. Immunocytochemical study of the distribuition of endocrine cells in the pancreas of the Brazilian sparrow species (Zonotrichia capensis subtorquata). Rev. Bras. Biol. = Braz. J. Biol., vol. 67, no. 4. p. 735-740.

PAN, QS., FANG, ZP. and HUANG, FJ., 2000. Identification, localization and morphology of APUD cells in gastroenteropancreatic system of stomach - containing teleosts. World J. Gastroenterol., vol. 6, no. 6, p. 842-847. 
RAWDON, BB. and ANDREW, A., 1981. An immunocytochemical survey of endocrine cells in the gastrointestinal tract of chicks at hatching. Cell Tissue Res., vol. 220, no. 2, p. 279-292.

RICHTER, G., STOCKMANN, F. and CONLON, J.M., 1986. Serotonin released into blood after food and pentagastrin studies in helthy subjects and in patients with metastatic carcinoid tumours. Gastroenterol., vol. 91, no. 3, p. 612-618.

SANTOS, C.M., NASCIMENTO, A.A., PERACCHI, A.L, DIAS, D., RIBEIRO, T.P., SALES, A. A., 2008. Comparative immunocytochemical study of endocrine cells in the digestive tract of two frugivorous bats: Artibeus cinerius and Sturnira lilium. Acta Histochem., vol. 110, p. 134-142.

SOLCIA, E., CAPELLA, C., VASSALLO, G. and BUFFA, R. 1975. Endocrine cells of the gastric mucosa. Int. Rev. Cytol., vol. 42 , p. 223-286
YAMADA, J., CAMPOS, VJM., KITAMURA, N., PACHECO, AC., YAMASHITA, T. and CABAMACHI, U., 1984. Immunocytochemical study of gastro-enteropancreatic (GEP) endocrine cells in the vampire bat (Desmodus rotundus). Gegenbaurs Morph. Jahrb., vol. 130, no. 6 , p. 845-856.

YAMADA, J., CAMPOS, VJM. and KITAMURA, N., 1986. An Immunohistochemical Study of endocrine cells in the pancreas of Caiman latirostris (Alligatorinae), with special reference to pancreatic motilin cells. Biomed. Res., vol. 7, no. 4 , p. $199-208$

YAMADA, J., BAOREN, L., DENG, Z., KITAMURA, N., YAMASHITA, T. and PHILLIPS, J., 1988. An immunohistochemical study of gut endocrine cells in two species of insetivorous vespertilinid Bat (chiroptera: Pipistrellus abramus and Plecotus auritus sacrimontis). Gegenbaurs Morph. Jahrb. vol., 134, p. 79-91. 